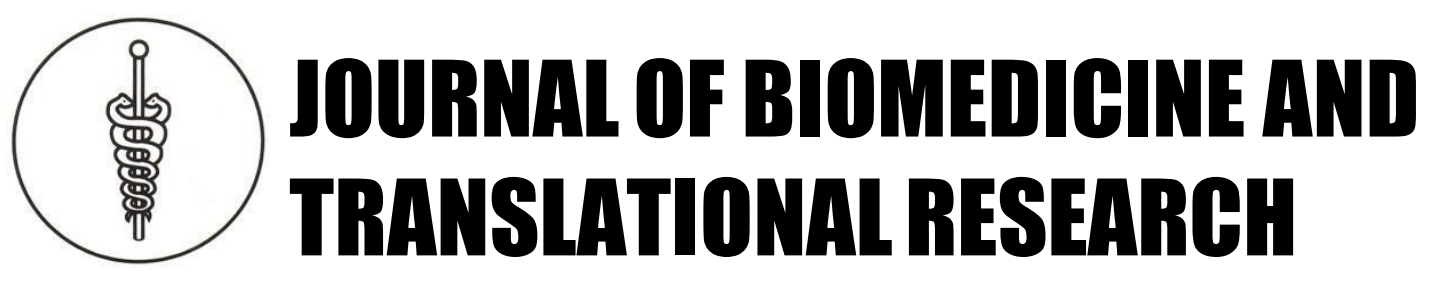

Copyright $@ 2017$ by Faculty of Medicine Diponegoro University and Indonesian Doctor Association, Central Java Region

\title{
Comparison of Prostaglandin Analogue and Selective Laser Trabeculoplasty Capability to Maintain Intraocular Pressure Fluctuation on Primary Open Angle Glaucoma
}

\author{
Sara L. Koentjoro" ${ }^{1}$, Maharani Cahyono ${ }^{2}$, Fifin L. Rahmi \\ ${ }^{1}$ Ophthalmology Resident of Diponegoro University/ Dr. Kariadi Hospital Semarang \\ ${ }^{2}$ Lecturer of Ophthalmology Department Glaucoma Subdivision, Diponegoro University/ Dr. Kariadi Hospital \\ Semarang
}

Article info

History :

Received : 11 May 2017

Accepted : 15 June 2017

Available : 23 June 2017

\begin{abstract}
Background: Glaucoma patients often come with intraocular pressure (IOP) that reach target pressure, but still have glaucoma progression due to IOP fluctuation. Water drinking test (WDT) can be used as a method to predict IOP fluctuation.

Purpose: To compare prostaglandin analogue (PGA) and selective laser trabeculoplasty (SLT) capability to maintain IOP fluctuation on primary open angle glaucoma (POAG).

Method: This clinical experimental research was conducted at Dr. Kariadi Hospital. Subjects were POAG patients selected with consecutive sampling. Intraocular pressure was measured before and after WDT. After WDT, IOP was measured every 15 minutes until 1 hour. Peak IOP and IOP fluctuation data were collected then analyzed with t-test.

Results: Forty two eyes from 30 POAG patients were analyzed. Twenty six eyes in PGA group and 16 eyes in SLT group. Most of the subjects were male with mild glaucoma degree. WDT increased IOP significantly on both groups. Mean IOP pre WDT was $14.58 \pm 2.580 \mathrm{mmHg}$ and $16.94 \pm 2.645 \mathrm{mmHg}$ in PGA and SLT groups. Mean peak IOP post WDT was $22.73 \pm 4.114 \mathrm{mmHg}$ and $25.75 \pm 5.859$ $\mathrm{mmHg}$ in PGA and SLT groups. Mean IOP fluctuation was $8.15 \pm 4.202 \mathrm{mmHg}$ and $8.81 \pm 5.344 \mathrm{mmHg}$ in PGA and SLT groups. Peak IOP and IOP fluctuation result analysis on both groups were not significantly different.

Conclusion: Prostaglandin analogue and SLT had equal capability to maintain IOP fluctuation but still higher than normal fluctuation $(>6 \mathrm{mmHg}$ ) that may affects glaucoma progression.
\end{abstract}

Keywords: Primary open angle glaucoma, prostaglandin analogue, selective laser trabeculoplasty water drinking test.

\section{INTRODUCTION}

Glaucoma represents a group of diseases defined by a characteristic optic neuropathy that is consistent with excavation and undermining of the neural and connective tissue elements of the optic disc and by the eventual development of distinctive patterns of visual dysfunction. ${ }^{1}$ As many as $13,4 \%$ of blind people in Indonesia suffered from glaucoma. ${ }^{2}$ Elevated intraocular pressure (IOP) is one of primary risk factors of glaucoma progression.
Glaucoma patients often come to the clinic with IOP that reach target pressure, but still have glaucoma progression. Twenty-four hours IOP fluctuation affects glaucoma progression. ${ }^{3}$ The current goal of glaucoma therapy is reaching target IOP with minimal IOP fluctuation to prevent glaucoma progression. Kumar et al said water drinking test (WDT) can be used as an alternative method to measure peak IOP and IOP fluctuation when patients come to the clinic. ${ }^{4}$ 
Prostaglandin analogue (PGA) is currently first line drug for primary open angle glaucoma (POAG) that can reduce IOP by $25-32 \%$. Another therapy for POAG is selective laser trabeculoplasty (SLT) that can reduce IOP by $20-25 \%{ }^{1}$

Lately, SLT not only used for patients who have maximum tolerance to medical therapy but also used for initial therapy of glaucoma. This study aim to compare PGA and SLT ability to maintain IOP fluctuation on POAG patients.

\section{METHODS}

This study was conducted at Dr. Kariadi Hospital from August 2016 until February 2017. Populations of study were POAG patients, which were diagnosed based on gonioscopy examination (open angle), funduscopy examination (cup and disc ratio > 0.3 with glaucomatous excavation, and medialization), the presence of visual field defect based on Humphrey perimetry with $\mathrm{MD} \geq-6 \mathrm{~dB}$ within one last year, and had optic nerve and retinal nerve fiber layer (RNFL) thickness OCT examinations within one last year. Glaucoma degree was determined by an average of RNFL thickness. Intervention consist of PGA therapy (latanoprost or travoprost) and $360^{\circ}$ SLT therapy of trabecular meshwork done by same surgeon. Length of therapy before reaching target IOP was not considered in this study. Samples of study were 30 POAG patients who fulfilled inclusion and exclusion criteria.

Inclusion criteria were 40-69 years old POAG patients who had reach IOP target pressure.

Table 1.Glaucoma Degree Assessment based onAverage RNFL Thickness ${ }^{5}$

\begin{tabular}{|c|c|}
\hline $\begin{array}{c}\text { Average } \\
\text { RNFL } \\
\text { Thickness }\end{array}$ & Glaucoma Degree \\
\hline$>80 \mu \mathrm{m}$ & Normal \\
\hline $70-79 \mu \mathrm{m}$ & Borderline, glaucoma suspect \\
\hline $60-69 \mu \mathrm{m}$ & Early thinning, early glaucoma \\
\hline $50-59 \mu \mathrm{m}$ & $\begin{array}{l}\text { Moderate thinning, moderate } \\
\text { glaucoma }\end{array}$ \\
\hline $40-49 \mu \mathrm{m}$ & $\begin{array}{l}\text { Advanced thinning, advanced } \\
\text { glaucoma }\end{array}$ \\
\hline$<30 \mu \mathrm{m}$ & $\begin{array}{l}\text { Advanced thinning, primary } \\
\text { retinal disease }\end{array}$ \\
\hline
\end{tabular}

Patients were classified based on target pressure for POAG using European Glaucoma Society (2003) guidelines as follows: ${ }^{6}$

- Early glaucoma: < $18 \mathrm{mmHg}$

- Moderate glaucoma: $<15 \mathrm{mmHg}$

- Advanced glaucoma: $<12 \mathrm{mmHg}$

- End-stage glaucoma: $<10 \mathrm{mmHg}$

Exclusion criteria consist of previous intraocular surgery (ex. cataract extraction, trabeculectomy surgery, etc), the presence of corneal defect, and systemic diseases (ex. congestive heart failure and renal disease).
Water drinking test (WDT) was used to predict peak IOP and IOP fluctuation. Ppatients were asked to drink $1,000 \mathrm{ml}$ mineral water within 10 minutes. Intraocular pressure was measured before WDT and subsequently at 15 minutes, 30 minutes, 45 minutes, and 60 minutes. Peak of IOP and IOP fluctuation were analyzed by SPSS.

\section{RESULTS}

Research subjects were POAG patients that divided into PGA group and SLT group. PGA group consist of 26 eyes from 19 patients, while SLT group consist of 16 eyes from 11 patients. Selective laser trabeculoplasty group had fewer patients than PGA group due to laser equipment error since November 2016. Mean age in PGA group was $58.79 \pm 6.40$ years, while in SLT group was 53.82 \pm 7.74 years (table 2).

Saphiro-Wilk test for PGA group showed all of data distributed normally. T-test IOP pre and post WDT (15 minutes, 30 minutes, 45 minutes, 60 minutes) in PGA group showed $\mathrm{p}$ value $<0.05$ in all pair data (table 4).

Saphiro-Wilk test for SLT group showed most data distributed normally, except IOP post WDT 60 minutes. T-test IOP pre and post WDT (15 minutes, 30 minutes, 45 minutes, 60 minutes) in SLT group showed $\mathrm{p}$ value $<0.05$ in all pair data (table 5).

Independent t-test was performed to analyze most PGA and SLT data, except in IOP post WDT 60 minutes (using Mann Whitney test) because the data was not distributed normally. The result of the statistical analysis showed IOP pre WDT, post WDT 30 minutes, 45 minutes, and 60 minutes were significantly different between PGA and SLT group with $\mathrm{p}$ value $<0.05$ (table 6).

\begin{tabular}{lccccc}
\multicolumn{5}{c}{ Table 2. Demographic Data of Subjects based on Sex and Age } \\
\hline \multicolumn{1}{c}{ Characteristics } & $\begin{array}{c}\text { PGA Group } \\
\text { Number } \\
\text { (person) }\end{array}$ & $\begin{array}{c}\text { Percentage } \\
(\%)\end{array}$ & $\begin{array}{c}\text { Number } \\
\text { (person) }\end{array}$ & $\begin{array}{c}\text { Percentage } \\
(\%)\end{array}$ & $p$ \\
\hline Sex & 11 & 57.9 & 6 & 54.5 & $0.579^{1}$ \\
Male & 8 & 42.1 & 5 & 45.5 & \\
Female & 2 & 10.6 & 3 & 27.3 & $0.430^{1}$ \\
Age (years) & 7 & 36.8 & 5 & 45.6 & \\
$40-49$ & 10 & 52.6 & 3 & 27.3 & \\
$50-59$ & 10 & & &
\end{tabular}

Table 3. Demographic Data of Subjects based on Glaucoma Degree

\begin{tabular}{ccccc}
\hline $\begin{array}{c}\text { Glaucoma } \\
\text { Degree }\end{array}$ & \multicolumn{2}{c}{ PGA Group } & \multicolumn{2}{c}{ SLT Group } \\
& $\begin{array}{c}\text { Number } \\
\text { (eyes) }\end{array}$ & $\begin{array}{c}\text { Percentage } \\
(\%)\end{array}$ & $\begin{array}{c}\text { Number } \\
\text { (eyes) }\end{array}$ & $\begin{array}{c}\text { Percentage } \\
(\%)\end{array}$ \\
\hline Early & 25 & 96.2 & 12 & 75.0 \\
Moderate & 1 & 3.8 & 4 & 25.0 \\
\hline
\end{tabular}

Giving PGA or SLT as monotherapy for glaucoma patients only fulfilled target pressure in mild degree glaucoma. Most of the subject of both group had mild degree of glaucoma, $96.2 \%$ in PGA group and $75.0 \%$ in SLT group (Table 3). 
Table 4. Water Drinking Test Result in PGA Group

\begin{tabular}{lcccc}
\hline & N & $\begin{array}{c}\text { Mean IOP } \pm \\
\text { SD } \\
(\mathbf{m m H g})\end{array}$ & $\begin{array}{c}\text { IOP } \\
\text { Min } \\
(\mathbf{m m H g})\end{array}$ & $\begin{array}{c}\text { IOP } \\
\text { Max } \\
\mathbf{m m H g})\end{array}$ \\
\hline Pre WDT & 26 & $14.58 \pm 2.580$ & 10 & 20 \\
15 minutes & 26 & $20.50 \pm 4.366$ & 14 & 28 \\
30 minutes & 26 & $19.69 \pm 4.873$ & 11 & 28 \\
45 minutes & 26 & $19.15 \pm 5.746$ & 8 & 30 \\
60 minutes & 26 & $18.58 \pm 5.457$ & 8 & 30 \\
Peak & 26 & $22.73 \pm 4.114$ & 14 & 30 \\
Fluctuation & 26 & $8.15 \pm 4.202$ & 0 & 16 \\
\hline
\end{tabular}

Table 5. Water Drinking Test Result in SLT Group

\begin{tabular}{lcccc}
\hline & N & $\begin{array}{c}\text { Mean IOP } \pm \\
\text { SD } \\
(\mathbf{m m H g})\end{array}$ & $\begin{array}{c}\text { IOP Min } \\
(\mathbf{m m H g})\end{array}$ & $\begin{array}{c}\text { IOP Max } \\
(\mathbf{m m H g})\end{array}$ \\
\hline Pre WDT & 16 & $16.94 \pm 2.645$ & 12 & 20 \\
15 minutes & 16 & $22.31 \pm 5.082$ & 14 & 31 \\
30 minutes & 16 & $24.31 \pm 6.183$ & 13 & 35 \\
45 minutes & 16 & $23.00 \pm 5.820$ & 13 & 33 \\
60 minutes & 16 & $23.19 \pm 5.319$ & 13 & 29 \\
Peak & 16 & $25.75 \pm 5.859$ & 15 & 35 \\
Fluctuation & 16 & $8.81 \pm 5.344$ & 0 & 16 \\
\hline
\end{tabular}

Paired t-test on both group showed IOP pre and post WDT were significantly different in all WDT pairs. This result showed that WDT raised IOP significantly on both group.

Peak IOP in PGA group appeared after 15 minutes post WDT, while in SLT group after 30 minutes.

Table 6. Statistical Analysis IOP Pre and Post Water Drinking Test between Prostaglandin Analogue and Selective Laser Trabeculoplasty Group

\begin{tabular}{lccc}
\hline & $\begin{array}{c}\text { PGA Group } \\
(\mathbf{M e a n} \pm \text { SD }) \\
\mathbf{m m H g}\end{array}$ & $\begin{array}{c}\text { SLT Group } \\
(\text { Mean } \pm \text { SD })\end{array}$ & p \\
$\mathbf{m m H g}$ & \\
\hline Pre WDT & $14.58 \pm 2.580$ & $16.94 \pm 2.645$ & $0.007^{* 1}$ \\
15 minutes & $20.50 \pm 4.366$ & $22.31 \pm 5.082$ & $0.227^{1}$ \\
30 minutes & $19.69 \pm 4.873$ & $24.31 \pm 6.183$ & $0.010^{* 1}$ \\
45 minutes & $19.15 \pm 5.746$ & $23.00 \pm 5.820$ & $0.042^{* 1}$ \\
60 minutes & $18.58 \pm 5.457$ & $23.19 \pm 5.319$ & $0.011^{* 2}$ \\
Peak & $22.73 \pm 4.114$ & $25.75 \pm 5.859$ & $0.057^{1}$ \\
Fluctuation & $\mathbf{8 . 1 5} \pm \mathbf{4 . 2 0 2}$ & $\mathbf{8 . 8 1} \pm \mathbf{5 . 3 4 4}$ & $\mathbf{0 . 6 5 9}^{1}$ \\
\hline
\end{tabular}

Statistical analysis showed that PGA and SLT group were significantly different at pre WDT, post WDT 30 minutes, 45 minutes, and 60 minutes with $\mathrm{p}$ value $<0.05$. This results showed the IOP different of two groups since before WDT, at 30 minutes, 45 minutes, and 60 minutes post WDT.

Meanwhile, both group showed IOP post WDT 15 minutes were not significantly different. It could happen because IOP raise continuously between two groups at 15 minutes.

Mean peak of IOP in PGA group was $22.73 \pm 4.114$ $\mathrm{mmHg}$, while in SLT group was $25.75 \pm 5.859$ $\mathrm{mmHg}$. Mean IOP fluctuation in PGA group was 8.15 $\pm 4.202 \mathrm{mmHg}(55.90 \% \pm 28.22 \%)$, while in SLT group was $8.81 \pm 5.344 \mathrm{mmHg}(52.01 \% \pm 31.55 \%)$.

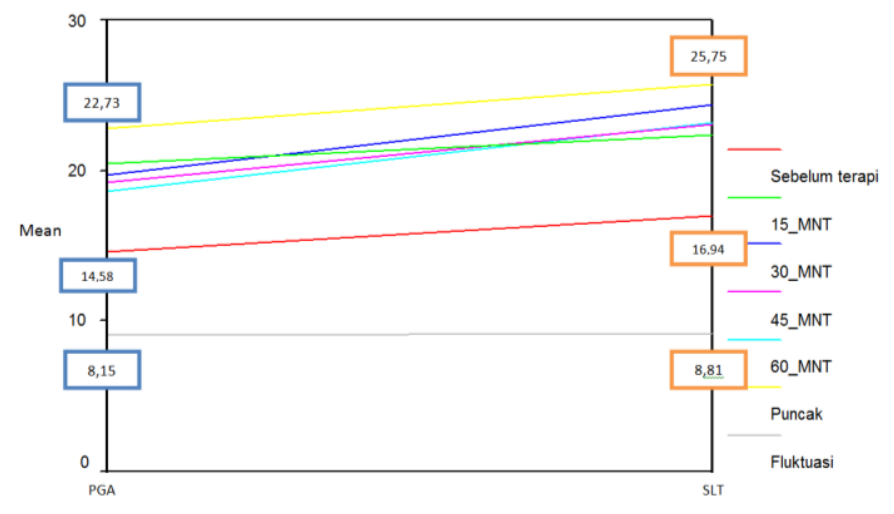

Figure 1. Graphic of Statistical Analysis Mean IOP Pre and Post Water Drinking Test between PGA and SLT Group

When observing presented value by the statistic, it appeared there was a considerable difference in peak IOP between PGA and SLT group, but statistical analysis result indicated that peak of IOP and IOP fluctuation between two groups were not significantly different. This could be influenced by significantly different mean IOP pre WDT that affected peak IOP on both group. It could be concluded that both PGA and SLT had equal potency to control IOP fluctuation.

Nagar $e t a l^{6}$ found that an IOP reduction after treated with latanoprost and SLT $360^{\circ}$ were not significantly different. Intraocular pressure reduction after treated with latanoprost was $>20 \%$ in $90 \%$ eyes, and $>30 \%$ in $78 \%$ eyes. While IOP reduction after treated with SLT $360^{\circ}$ was $>20 \%$ in $82 \%$ eyes, and $>30 \%$ in $59 \%$ eyes. The IOP reduction between two groups was not significantly different.

Katz LJ et $a l^{7}$ also found that IOP reduction between PGA group and SLT group were similar after 9-12 months follow up. Mean IOP reduction in PGA group was $7.0 \mathrm{mmHg}$, while in SLT group was $6.3 \mathrm{mmHg}$. Both Nagar et $a l^{6}$ and Katz LJ et al concluded IOP reduction after treated with PGA and SLT were not significantly different .

Nagar et $a l^{8}$ and Kiddee et $a l^{9}$ studied IOP fluctuation after treatment of PGA and SLT. Based on Nagar et $a l^{8}$ study, SLT and latanoprost had significant effect on IOP reduction and IOP fluctuation, but latanoprost more capable on reducing IOP fluctuation. Intraocular fluctuation reduction was $50 \%$ in SLT group, and $83 \%$ in latanoprost group after 4-6 months follow up.

Kiddee et $\mathrm{al}^{9}$ study showed that travoprost and SLT could significantly reduced IOP in POAG patients. Travoprost was more capable in controlling IOP fluctuation than SLT especially at daytime. During nighttime, both of travoprost and SLT could significantly control IOP fluctuation.

This study result concluded both therapy had equal potency to control IOP fluctuation, which was different with uther studies. It could be caused by age 
different of the subjects that influenced patient response to therapy. In Kiddee et $a l^{9}$ study, mean age of the patients in travoprost group was $62.3 \pm 13.1$ years, while in SLT group was $68.0 \pm 10.0$ years. In this study, mean age of patients in PGA group was $58.79 \pm 6.40$ years, while in SLT group was $53.82 \pm$ 7.74 years.

Nagar et $a l^{8}$ observed the diurnal curve after 4-6 months follow up of treatment, while this study was at point prevalence using cross sectional design. The different number of subjects between PGA and SLT group in this study could cause different result with previous study.

Water drinking test were raised an IOP significantly on both group. Therefore both PGA and SLT could not prevent IOP fluctuation until normal (2-6 $\mathrm{mmHg})$. However, mean of IOP fluctuation on both groups were lower than IOP fluctuation on glaucoma patients without therapy $(\geq 10 \mathrm{mmHg}){ }^{1}$

There were some limitations in this study including short period of study, different number of subjects between two groups, the subjects could not represent all of glaucoma degree, no equal period of fasting, no diet recall, and different diurnal time of performing WDT. Besides, there was significantly different IOP pre WDT between two groups that caused difference of peak IOP although not significantly different.

\section{CONCLUSION}

There was no significant difference of WDT result (IOP fluctuation) on POAG patients treatment with PGA and with SLT. Prostaglandin Analogue and SLT had equal capability to maintain IOP fluctuation but still higher than normal fluctuation (> $6 \mathrm{mmHg}$ ). Prostaglandin analogue or SLT as monotherapy of POAG cannot control IOP normal fluctuation. Additional therapy or combination therapy is required to reach normal IOP fluctuation.

\section{REFERENCES}

1. Cioffi GA, Durcan FJ, Girkin CA, Gupta N, PiltzSeymour JR, Samuelson TW, et al. Basic and clinical science course: Glaucoma section 10. San Fransisco: American Academy of Ophthalmology; 2014. p 73-78, $166,180$.

2. Gangguan penglihatan masih menjadi masalah kesehatan. Kementrian Kesehatan Republik Indonesia [serial online]. 2010 [cited 2015 Sep 27]. Available from:

http://www.depkes.go.id/pdf.php?id=845

3. Bhartiya $\mathrm{S}$, Ichhpujani $\mathrm{P}$. The need to maintain intraocular pressure over 24 hours. Jaypee Journal [serial online]. 2012 Sep [cited 2015 Sep 28] 6 (3): 120-123.

Available from:

http://www.jaypeejournals.com/eJournals/ShowText.a spx $?$ ID $=3222 \&$ Type $=$ FREE $\&$ TYP $=$ TOP $\& I N=$ eJourn als/images/JPLOGO.gif \&IID=247\&isPDF=YES

4. Kumar RS, de Guzman MH, Ong PY, Goldberg I. Does peak intraocular pressure measured by water drinking test reflect peak circadian levels? A pilot study. Pubmed [serial online]. 2008 May [cited 2015 Sep 28]. Available from:

http://www.ncbi.nlm.nih.gov/pubmed/18700916

5. Bressler NM, Ahmed IIK, Nguyen QD, Shah M, Do DV, dan Hwang T. The stratus OCT primer: Essential OCT. Baltimore : Wilmer Eye Institute; 2006. p 37-49

6. Detry-Morel M. General review: currents on target intraocular pressure and intraocular pressure fluctuations in glaucoma management. Bull. Soc. belge Ophtalmol [serial online]. 2008 May [cited 2017 Mar 10]; 308: 38. Available from :

www.ophthalmologia.be/download.php?dof_id=54

7. Rudnicka AR, Isa SM, Owern CG, Cook DG, Ashby D. Variations in primary open-angle glaucoma prevalence by age, gender, and race: A bayesian metaanalysis. Investigative Ophthalmology \& Visual Science. [serial online]. 2006 Oct [cited 2017 Mar 13]; 47: 4254-4261. Available from: http://iovs.arvojournals.org/article.aspx ?articleid=2124 829

8. Nagar M, Ogunyomade A, O'Brart DP, Howes F, Marshall J. A randomized, prospective study comparing selective laser trabeculoplasty with latanoprost for the control of intraocular pressure in ocular hypertension and open angle glaucoma. $\mathrm{Br} \mathbf{J}$ Ophthalmol. [serial online]. 2005 Nov [cited 2017 Mar 18]; 89(11): 1413-7. Available from: https://www.ncbi.nlm.nih.gov/pubmed/16234442

9. Katz LJ, Steinmann WC, Kabir A, Molineaux J, Wizov SS, Marcellino G, et al. Selective laser trabeculoplasty versus medical therapy as initial treatment of glaucoma: a prospective, randomized trial. PubMed. [serial online]. 2012 Sep. [cited 2015 Nov 29]. Available from:http://www.ncbi.nlm.nih.gov/pubmed/21543992

10. Nagar M, Luhishi E, Shah N. Intraocular pressure control and fluctuation: the effect of treatment with selective laser trabeculoplasty. Pubmed [serial online]. 2009 [cited 2015 Sep 29]. Available from: http://www.ncbi.nlm.nih.gov/pubmed/19106150

11. Kiddee W, Atthavuttisilp S. The effects of selective laser trabeculoplasty and travoprost on circadian intraocular pressure and fluctuations. Medicine. [serial online]. 2017 Jan [cited 2017 Mar 18] 96:6 (e6047). Available from: http://journals.lww.com/mdjournal/Fulltext/2017/0210 0/The_effects_of_selective_laser_trabeculoplasty_and. 31.aspx 